\title{
Assessing the external costs and the economic viability of the Greek steel industry
}

\author{
D. Damigos \& D. Kaliampakos \\ School of Mining and Metallurgical Engineering, \\ National Technical University of Athens, Greece
}

\begin{abstract}
In recent years, legislative requirements and environmental policies at European, as well as national, level seek to internalize the environmental impacts that have been traditionally viewed as externalities, in order to come up with more informed and fair choices. The IPPC (Integrated Pollution Prevention and Control) Directive 96/61/EC lays down a framework requiring Member States to issue operating permits for certain installations based on best available techniques (BAT) in order to achieve a high level of protection of the environment. This framework gives clearly importance to economic aspects. More specific, the environmental effects of an installation or a sector are compared against the costs for taking preventive measures against pollution, in order to determine which, if any, meet the criteria of BAT. The scope of the paper is to explore the effects of BAT implementation in the Greek steel sector towards eliminating air emissions from steel production. The analysis is based on pollutant emissions gathered by reports prepared for the European Pollutant Emission Register (EPER) and on external costs, in terms of euros per tonne of pollutant emitted, generated by European Programmes. The externalities estimated are compared to important financial indicators of individual steel producers and of the sector, as well, in order to provide necessary input for assessing the economic viability of the industry under investigation.
\end{abstract}

Keywords: externalities, steel industry, air emissions, best available techniques.

\section{Introduction}

It is commonly accepted that iron and steel, together with coal, have played an important role in the development of human civilisation. These were the 
principal materials upon which the industrial revolution was based, founding numerous uses in agriculture, construction, manufacturing of machinery, medicine, etc.

World crude steel production has grown exponentially in the second half of the twentieth century, rising from 189 million metric tons in 1950, to 848 million metric tons in 2000. Over the last decade, world crude steel production has grown by $56.5 \%$, from 799 to million metric tons in 1997 to 1,250 in 2006. In the same period, EU-25 crude steel production has increased only by $7.5 \%$, as shown in Table 1, and the European share of world crude steel production has steadily declined from $23.1 \%$ in 1996 to $15.9 \%$ in 2006 [1].

Table 1: $\quad$ Crude steel production 1997-2006 ('000 metric tons).

\begin{tabular}{|l|r|r|r|r|r|r|r|r|r|r|}
\hline & $\mathbf{1 9 9 7}$ & $\mathbf{1 9 9 8}$ & $\mathbf{1 9 9 9}$ & $\mathbf{2 0 0 0}$ & $\mathbf{2 0 0 1}$ & $\mathbf{2 0 0 2}$ & $\mathbf{2 0 0 3}$ & $\mathbf{2 0 0 4}$ & $\mathbf{2 0 0 5}$ & $\mathbf{2 0 0 6}$ \\
\hline EU-15 & 159,867 & 159,888 & 155,209 & 163,358 & 158,497 & 158,686 & 160,975 & 169,071 & 165,112 & 173,233 \\
\hline EU-25 & 184,568 & 182,424 & 175,943 & 186,694 & 180,546 & 180,896 & 184,505 & 194,189 & 187,213 & 198,462 \\
\hline $\begin{array}{l}\text { Other } \\
\text { Europe }\end{array}$ & 26,367 & 25,449 & 22,390 & 23,707 & 24,604 & 26,615 & 29,288 & 32,139 & 33,186 & 36,378 \\
\hline C.I.S. & 80,558 & 73,950 & 85,657 & 98,489 & 99,619 & 101,089 & 106,220 & 113,112 & 112,876 & 119,766 \\
\hline $\begin{array}{l}\text { North } \\
\text { America }\end{array}$ & 129,489 & 129,945 & 130,044 & 135,353 & 119,858 & 122,949 & 126,161 & 134,021 & 127,631 & 131,655 \\
\hline $\begin{array}{l}\text { South } \\
\text { America }\end{array}$ & 36,966 & 36,121 & 34,594 & 39,110 & 37,372 & 40,861 & 43,047 & 45,875 & 45,316 & 45,298 \\
\hline Africa & 12,856 & 12,806 & 12,818 & 13,827 & 14,916 & 15,807 & 16,289 & 16,706 & 17,995 & 18,780 \\
\hline M.East & 9,929 & 9,065 & 9,779 & 10,780 & 11,690 & 12,492 & 13,443 & 14,253 & 15,257 & 15,376 \\
\hline Asia & 308,633 & 297,873 & 308,799 & 331,880 & 353,801 & 394,928 & 442,394 & 510,095 & 598,083 & 675,589 \\
\hline Oceania & 9,589 & 9,697 & 8,946 & 7,832 & 7,859 & 8,292 & 8,397 & 8,300 & 8,646 & 8,691 \\
\hline World & 798,954 & 777,330 & 788,970 & 847,671 & 850,266 & 903,929 & 969,743 & $1,068,691$ & $1,146,203$ & $1,249,997$ \\
\hline
\end{tabular}

Source: IISI.

Although investments and employment have diminished, steel industry remains a key sector for Europe's economy and competitiveness, since it accounts for about $1.8 \%$ of the value added and $1.5 \%$ of employment in EU manufacturing [2]. For this reason, the European Commission has been concerned about the crisis in the European steel industry and has aimed at stabilising the intra-Community steel market. Towards this direction the European Parliament, in its resolution of 12 February 2004, called for measures to be taken at Community level to defend Europe's iron and steel industry (i.e. regulation of unfair competition from outside the EU). Further, in its resolution of 24 February 2005, Parliament invited the Commission, after the expiry of the ECSC Treaty, to present a strategy for the future prospects of the steel sector in order to promote independent European capacity in this sector [2].

Nevertheless, it is known that EU policy recognizes that economic development must be sustainable with respect to the environment and from an environmental viewpoint, steel industry is an important emitter of air pollutants (i.e. dust, $\mathrm{NO}_{\mathrm{x}}, \mathrm{SO}_{2}$, etc.) and $\mathrm{CO}_{2}$ and is highly intensive in both materials and energy. During the last 20 years, the energy required to produce a tonne of steel has fallen by $40 \%$, and throughout the nineties there has been a reduction of $20 \%$ in $\mathrm{CO}_{2}$ emissions for the industry [2]. In addition, steel is the most recycled material in the world, since it is $100 \%$ recyclable with no downgrading in 
quality. It is estimated that about $47 \%$ of EU steel production is made from recycled scrap, while recycling of steel allows the saving world-wide of about 600 million tonnes of iron ore and 200 million tonnes of coke each year [3]. Yet, air pollution remains an important issue.

In some countries, the environmental pollution caused by steel production is a matter of trade union concern. For example, in Italy, the unions consider the introduction of pollution-control systems in pursuit of zero environmental impact to be of priority importance, asking the government to set up a permanent forum for discussion on industrial policies in the medium to long term [4]. In general, however, the steel industry is mainly affected by EU and national policies and measures. The EU environmental policy context, and consequently its adoption at national level, is driven by the increased prominence of sustainable development and it emphasizes in market-based instruments at ex ante (e.g. permission processes) as well as ex post procedures (e.g. liability).

Although there are several Directives affecting the steel industry, this paper emphasizes on the requirements set by the IPPC (Integrated Pollution Prevention and Control) Directive 96/61/EC [5]. More specific, the aim of this paper is to determine whether or not the implementation of a BAT package in pursuit of practically zero air emissions is considered to be viable for the Greek steel industry under the IPPC framework. The paper focuses on the external costs and the resilience of the individual companies and the sector as a whole, considering annual emissions of specific air pollutants and a number of financial ratios.

\section{Evaluating the economic viability of a sector}

The IPPC Directive lays down a framework requiring Member States to issue operating permits for certain installations, including steel units. The importance of this Directive consists in the fact that these permits must contain conditions based on best available techniques (BAT) to achieve a high level of protection of the environment. According to the Article 2.11 of the IPPC Directive, "best" means the most effective ones in achieving a high general level of protection of the environment as a whole and "available" means those techniques developed on a scale which allows implementation in the relevant industrial sector, under economically and technically viable conditions.

In order to assist in the determination of BAT under the IPPC Directive, the European IPPC Bureau (EIPPCB) organizes the exchange of information and produces BAT reference documents (BREFs), which Member States are required to take into account. Among others, the EIPPCB has prepared a horizontal BREF entitled "Economics and Cross-media Effects (ECME)" [6]. According to the methodology described in the abovementioned BREF, the selection of BAT under IPPC Directive takes into account the likely costs and benefits of pollution reduction measures as well as the results of an environmental cross-media assessment in order to avoid creating a new environmental problem when solving another. At the final step of the methodology, an evaluation procedure is set out in order to ensure that whichever technique is determined to be BAT does not undermine the economic viability of the industrial sector implementing that measure. 
Determining whether implementing a BAT option in a sector is 'economically viable', depends on the capacity that the sector has to absorb the extra cost, or to transfer these costs on to the customer or suppliers [6]. The ability of the sector to absorb the costs depends on its resilience whereas the ability of the sector to pass the costs on depends on the structure of the industry and the market, as well.

The industry structure involves a number of sector's characteristics, such as the size and the number of installations, the production processes applied, the barriers that prevent players entering or leaving the market, etc. As far as the market structure is concerned, several factors influence the ability of the firms to pass on the costs of BAT implementation to the consumers, such as the extent of the market (i.e. local or global), the price elasticity of the commodities produced by the firms, the competition among existing firms and the threat of new entrants, etc.

The 'resilience' refers to the sector's ability to absorb the increased costs of environmental improvement in the short-, medium- and long-term. In order to ensure this viability, firms in the sector will need to be able to generate sufficient financial returns on an ongoing basis. There are several financial ratios that are used to describe the economic situation of a company. These financial ratios can be useful for evaluating company's resilience, but they can be difficult to apply to a sector. Hence, when carrying out the viability assessment, an 'average' (hypothetical) company can be used by averaging, for example, the annual accounts for the sample of the companies of the sector under investigation. However, the results can easily be distorted by the selection of companies in the sample. These distortions are more likely in cases where there are fewer companies in the sector or where there are some particularly badly or well performing companies.

\section{Evaluating the economic viability of the Greek steel sector}

\subsection{Overview of the Greek steel industry}

Steel sector plays an important role in Greek manufactory industry. The production of Greek steel industry increased by almost $140 \%$ over the last decade, that is 20 times more than the average increase rate in EU-25. Greece produced 2.4 million metric tons of crude steel in 2006 and was ranked $39^{\text {th }}$ in the world.

Strictly speaking, the steel industry involves the production of crude steel, semi-products, hot-rolled finished products, continuously cast products, coldrolled sheets and plates, and coated sheets. Nevertheless, in the analysis presented only those companies involved in crude steel production by scrap melting are examined.

One of the most important characteristics of the Greek steel industry, which is common in the majority of countries, is its high degree of concentration due to the increasing scale of production units as well as mergers and acquisitions between companies and groups. In Greece, only five companies account for the total of steel output and employment, namely: 
- Halyvourgiki S.A.

- SOVEL S.A.

- SIDENOR S.A.

- Halyvourgia Thessalias S.A.

- Hellenic Halyvourgia S.A.

These five companies belong to three groups, i.e. Halyvourgiki, SIDENOR SOVEL and Halyvourgia Thessalias - Hellenic Halyvourgia, which operate the following production units:

\section{Halyvoyrgiki}

Halyvourgiki's melt shop is located at Aspropyrgos, Attiki Region. Steel is produced in the form of square cross section prisms (billets). The basic production stages of the steel making process include melting of steel scrap, secondary metallurgy (fine adjustments to steel composition) and continuous casting of molten steel. The melt shop includes electric arc furnaces, with 100ton capacity each, for the melting of steel scrap and a ladle furnace where secondary metallurgy takes place [7].

\section{SIDENOR - SOVEL}

The group operates two units at Thessaloniki (Northern Greece) and Almyros, Magnesia (Central Greece). As far as steel production is concerned, the Thessaloniki plant includes one $80 \mathrm{t}$ electric arc furnace for melting of steel scrap and one 80 tn ladle furnace for secondary metallurgy. The Almyros industrial complex comprised of a steel plant, rolling-mill facilities, a construction mesh production unit, a pipe manufacturing unit and auxiliary units. Steel production from scrap takes place in one 130 tn electric arc furnace and one 130 th ladle furnace [8].

\section{Halyvourgia Thessalias - Hellenic Halyvourgia}

The group owns two units at Aspropyrgos (Attiki) and Velestino, Magnesia (Central Greece). The Aspropyrgos industrial complex is comprised by a melt shop, a rolling-mill for long products, a wire mesh plant, as well as covered warehouses. The Velestino melt shop has an annual production capacity in semifinished product (billet) that exceeds 700.000 tons. The industrial complexes include electric arc furnaces for melting of steel scrap and ladle furnaces for secondary metallurgy [9].

All the abovementioned facilities operate advanced control systems (i.e. fume and water treatments plants) and use BAT in order to minimize environmental impacts of steel production. In addition, the companies apply environmental management systems, according to the international standard ISO 14001:2004.

\subsection{Assessing the externalities of the sector}

In order to assess the externalities of the Greek steel sector in monetary terms for the purposes of this analysis, two types of information were considered, namely the annual emissions of the plants and the external cost of the pollutant expressed as $€ /$ tn emitted.

As far as the emissions are concerned, values declared by the firms for the European Pollutant Emission Register (EPER) report were used. It should be 
mentioned that according to the EPER Decision [10] the report covers 50 pollutants which must be included if the threshold values indicated in Annex A1 of the EPER Decision are exceeded. Given that in the vast majority of the cases the sector's emissions do not exceed the threshold values, EPER database does not include all the information needed; therefore the company statements for the 2004 emissions were used (Table 2).

Table 2: $\quad$ Steel sector's emissions in 2004 (kgr).

\begin{tabular}{|l|c|r|r|r|}
\hline & \multicolumn{1}{|c|}{$\mathbf{N O}_{\mathbf{x}}$} & \multicolumn{1}{c|}{$\mathbf{S O}_{2}$} & \multicolumn{1}{c|}{ PM10 } & \multicolumn{1}{c|}{ NMVOC } \\
\hline SOVEL & 56,000 & 365,000 & 20,700 & 0 \\
\hline SIDENOR & 85,383 & 30,627 & 15,663 & 0 \\
\hline Halyvourgia Thessalias & 37,800 & 10,210 & 6,760 & 36,110 \\
\hline Hellenic Halyvourgia & 36,454 & 6,432 & 4,634 & 25,150 \\
\hline Halyvoyrgiki & 25,000 & 44,928 & 0 & 0 \\
\hline
\end{tabular}

Following the 'ECME' BREF guidelines, the external costs derived from the cost benefit analysis in the Clean Air for Europe (CAFE) programme, were applied [11]. Given that external costs have only been derived for a few air pollutants, namely $\mathrm{PM}_{2.5}, \mathrm{NH}_{3}, \mathrm{SO}_{2}$, $\mathrm{NOx}$ and VOCs, values proposed for $\mathrm{PM}_{2.5}$ and VOCs were used for estimating externalities of PM10 and NMVOCs, respectively.

It is underlined that the external costs in the CAFE programme relate only to human health and crop damages. Ecosystem externalities could not be monetised due to lack of data. In addition, many assumptions have been made, both when establishing the predicted environmental effects and when deriving values for the predicted impacts, which may push the results either way, up or down. Hence, it is recommended that ranges are used and sensitivities explored.

Table 3: $\quad$ Marginal damage ( $€$ per tonne emission).

\begin{tabular}{|l|r|r|}
\hline & \multicolumn{1}{|c|}{ Low value } & \multicolumn{1}{c|}{ Upper value } \\
\hline NO $_{\mathbf{x}}$ & 840 & 1,900 \\
\hline SO $_{2}$ & 1,400 & 4,000 \\
\hline PM10 & 8,600 & 25,000 \\
\hline NMVOC & 280 & 880 \\
\hline
\end{tabular}

Table 4: $\quad$ Annual external costs $(€)$ per pollutant of Greek steel industry.

\begin{tabular}{|l|r|r|r|r|r|r|r|r|}
\hline & \multicolumn{2}{|c|}{ NO $_{\mathbf{x}}$} & \multicolumn{2}{c|}{ SO $_{2}$} & \multicolumn{2}{c|}{ PM10 } & \multicolumn{2}{c|}{ NMVOC } \\
\cline { 2 - 10 } & Lower & \multicolumn{1}{c|}{ Upper } & \multicolumn{1}{c|}{ Lower } & \multicolumn{1}{c|}{ Upper } & \multicolumn{1}{c|}{ Lower } & Upper & \multicolumn{1}{c|}{ Lower } & Upper \\
\hline SOVEL & 47,040 & 106,400 & 511,000 & $1,460,000$ & 178,020 & 517,500 & 0 & 0 \\
\hline SIDENOR & 71,722 & 162,228 & 42,878 & 122,508 & 134,702 & 391,575 & 0 & 0 \\
\hline $\begin{array}{l}\text { Halyvourgia } \\
\text { Thessalias }\end{array}$ & 31,752 & 71,820 & 14,294 & 40,840 & 58,136 & 169,000 & 10,111 & 31,777 \\
\hline $\begin{array}{l}\text { Hellenic } \\
\text { Halyvourgia }\end{array}$ & 30,621 & 69,263 & 9,005 & 25,728 & 39,852 & 115,850 & 7,042 & 22,132 \\
\hline Halyvoyrgiki & 21,000 & 47,500 & 62,899 & 179,712 & 0 & 0 & 0 & 0 \\
\hline Sector & 202,135 & 457,210 & 640,076 & $1,828,788$ & 410,710 & $1,193,925$ & 17,153 & 53,909 \\
\hline
\end{tabular}


Bearing these remarks in mind, in order to estimate the externalities in the case of the Greek steel industry, the lower and the upper values suggested by CAFE for pollutants emitted in Greece were used (Table 3). The lower and upper estimates of the analysis are presented in Tables 4 and 5.

Table 5: $\quad$ Total annual external costs $(€)$ of Greek steel industry.

\begin{tabular}{|l|r|r|}
\hline \multirow{2}{*}{} & \multicolumn{2}{|c|}{ Total } \\
\cline { 2 - 3 } & \multicolumn{1}{|c|}{ Lower } & \multicolumn{1}{c|}{ Upper } \\
\hline SOVEL & 736,060 & $2,083,900$ \\
\hline SIDENOR & 249,301 & 676,311 \\
\hline Halyvourgia Thessalias & 114,293 & 313,437 \\
\hline Hellenic Halyvourgia & 86,521 & 232,973 \\
\hline Halyvoyrgiki & 83,899 & 227,212 \\
\hline Sector & $1,270,074$ & $3,533,832$ \\
\hline
\end{tabular}

\subsection{Evaluating the economic viability of the sector}

In order to examine the financial burden that will be placed on the steel industry and its firms from implementing technologies that will minimize air emissions, two measures were used, namely:

- $\quad$ Earnings before interest and taxes (EBIT)

- $\quad$ Earnings before taxes (EBT)

'EBIT' is regarded as the most appropriate indicator of operational performance because the comparisons are not influenced by the particular way that the company is financed. 'EBT' is an important profitability measure because deducts all expenses from revenue except from the payment of tax. Thus, it provides a good idea of fluctuations in companies' profits from year to year. In order to be consistent with the emission reference year, the profitability measures were collect from the 2004 financial statements (Table 6).

Table 6: $\quad$.Profitability measures ('000 €) of Greek steel industry in 2004.

\begin{tabular}{|l|r|r|}
\hline & \multicolumn{1}{|c|}{ EBIT } & \multicolumn{1}{c|}{ EBT } \\
\hline SOVEL & 40,489 & 38,642 \\
\hline SIDENOR & 28,543 & 20,790 \\
\hline Halyvourgia Thessalias & 11,852 & 6,831 \\
\hline Hellenic Halyvourgia & 3,729 & 2,134 \\
\hline Halyvoyrgiki & 14,632 & 4,144 \\
\hline
\end{tabular}

The external costs were expressed as a percentage of the above measures in order to form the 'externality' ratios. Although there is no pre-determined percentage of accepting the results, these values provide useful insights for assessing the economic viability of the sector; it is evident that firms with lower 'externality' ratios will find it easier to absorb the costs of implementing BAT. The results of the analysis are presented in Table 7. 
Table 7: 'Externality’ ratios (\%) of Greek steel industry in 2004.

\begin{tabular}{|c|c|c|c|c|c|c|}
\hline & SOVEL & SIDENOR & $\begin{array}{c}\text { Halyvourgia } \\
\text { Thessalias }\end{array}$ & $\begin{array}{c}\text { Hellenic } \\
\text { Halyvourgia }\end{array}$ & $\begin{array}{c}\text { Haly- } \\
\text { voyrgiki }\end{array}$ & Sector \\
\hline \multicolumn{7}{|l|}{$N O_{x}$} \\
\hline$\%$ EBIT & $0.12 \%$ & $0.25 \%$ & $0.27 \%$ & $0.82 \%$ & $0.14 \%$ & $0.20 \%$ \\
\hline upper & $0.26 \%$ & $0.57 \%$ & $0.61 \%$ & $1.86 \%$ & $0.32 \%$ & $0.46 \%$ \\
\hline$\%$ EBT lower & $0.12 \%$ & $0.34 \%$ & $0.46 \%$ & $1.43 \%$ & $0.51 \%$ & $0.28 \%$ \\
\hline upper & $0.28 \%$ & $0.78 \%$ & $1.05 \%$ & $3.25 \%$ & $1.15 \%$ & $0.63 \%$ \\
\hline \multicolumn{7}{|l|}{$\mathrm{SO}_{2}$} \\
\hline$\%$ EBIT & $1.26 \%$ & $0.15 \%$ & $0.12 \%$ & $0.24 \%$ & $0.43 \%$ & $0.64 \%$ \\
\hline upper & $3.61 \%$ & $0.43 \%$ & $0.34 \%$ & $0.69 \%$ & $1.23 \%$ & $1.84 \%$ \\
\hline \%EBT lower & $1.32 \%$ & $0.21 \%$ & $0.21 \%$ & $0.42 \%$ & $1.52 \%$ & $0.88 \%$ \\
\hline upper & $3.78 \%$ & $0.59 \%$ & $0.60 \%$ & $1.21 \%$ & $4.34 \%$ & $2.52 \%$ \\
\hline \multicolumn{7}{|l|}{ PM10 } \\
\hline$\%$ EBIT & $0.44 \%$ & $0.47 \%$ & $0.49 \%$ & $1.07 \%$ & $0.00 \%$ & $0.41 \%$ \\
\hline upper & $1.28 \%$ & $1.37 \%$ & $1.43 \%$ & $3.11 \%$ & $0.00 \%$ & $1.20 \%$ \\
\hline$\%$ EBT lower & $0.46 \%$ & $0.65 \%$ & $0.85 \%$ & $1.87 \%$ & $0.00 \%$ & $0.57 \%$ \\
\hline upper & $1.34 \%$ & $1.88 \%$ & $2.47 \%$ & $5.43 \%$ & $0.00 \%$ & $1.65 \%$ \\
\hline \multicolumn{7}{|l|}{ NMVOC } \\
\hline$\%$ EBIT & $0.00 \%$ & $0.00 \%$ & $0.09 \%$ & $0.19 \%$ & $0.00 \%$ & $0.02 \%$ \\
\hline upper & $0.00 \%$ & $0.00 \%$ & $0.27 \%$ & $0.59 \%$ & $0.00 \%$ & $0.05 \%$ \\
\hline$\%$ EBT lower & $0.00 \%$ & $0.00 \%$ & $0.15 \%$ & $0.33 \%$ & $0.00 \%$ & $0.02 \%$ \\
\hline upper & $0.00 \%$ & $0.00 \%$ & $0.47 \%$ & $1.04 \%$ & $0.00 \%$ & $0.07 \%$ \\
\hline \multicolumn{7}{|c|}{ Total externalities } \\
\hline$\%$ EBIT & $1.82 \%$ & $0.87 \%$ & $0.96 \%$ & $2.32 \%$ & $0.57 \%$ & $1.28 \%$ \\
\hline upper & $5.15 \%$ & $2.37 \%$ & $2.64 \%$ & $6.25 \%$ & $1.55 \%$ & $3.56 \%$ \\
\hline$\%$ EBT lower & $1.90 \%$ & $1.20 \%$ & $1.67 \%$ & $4.05 \%$ & $2.02 \%$ & $1.75 \%$ \\
\hline upper & $5.39 \%$ & $3.25 \%$ & $4.59 \%$ & $10.92 \%$ & $5.48 \%$ & $4.87 \%$ \\
\hline
\end{tabular}

\subsection{Discussion of the results}

According to the 2004 emission data, the externalities of the Greek steel industry, due to the $\mathrm{SO}_{2}, \mathrm{PM} 10, \mathrm{NO}_{\mathrm{x}}$ and NMVOCs emissions range between 1.27 and 3.53 million $€$. About $40 \%$ of this external cost is attributed to the $\mathrm{SO}_{2}$ emissions of SOVEL. The latter company is responsible for almost $60 \%$ of the sector's externalities.

With the exceptions of SOVEL and Halyvourgiki (the latter did not report PM10 emissions probably because they did not exceed the threshold of the EPER Decision), PM10 seems to be the most important source of externalities for the steel companies, followed by NOx. NMVOCs are insignificant from this point of view. Yet, it is mentioned that the external costs of VOCs estimated by the CAFE programme involve serious omissions, because of the failure to account for organic aerosols as well as for impacts associated with long-term (chronic) exposure to ozone.

As far as the 'externality' ratios are concerned, the total environmental costs are estimated between $1.28 \%$ and $3.56 \%$ of the sector's EBIT and between 
$1.75 \%$ and $4.87 \%$ of its EBT. Hellenic Halyvourgia presents the worst performance, since the company's externalities range between $2.32 \%$ and $6.25 \%$ of EBIT and between $4.05 \%$ and $10.92 \%$ of EBT. These figures are almost two times higher than the overall ratios of the sector. On the opposite side, SIDENOR is the most resilient company given that the external costs vary between $0.87 \%$ and $2.37 \%$ of EBIT and $1.20 \%$ and $3.25 \%$ of EBT. The results of the other companies lie in the middle.

\section{Concluding remarks}

From the analysis presented, it becomes evident that determining whether implementing BAT in a sector is 'economically viable' under the IPPC framework is not an easy task due to the diversity of the industrial units involved. Considering the Greek steel sector, installation of environmental systems in order to achieve practically zero air emissions would imply different financial burdens to the steel companies under investigation. Hence, an in-depth analysis would be probably more appropriate.

The approach presented offers certain advantages and it could prove to be beneficial in different levels of decision-making process. It recognizes the most significant environmental stressors and it highlights the most 'vulnerable' firms to changes in operating and capital expenses associated with implementing BAT. For example, in the case presented it was indicated that the external cost of the sector was mainly caused by $\mathrm{SO}_{2}$ and PM10 emissions. Hence, process integrated measures or end-of-pipe techniques should focus on those pollutants. In addition, the 'externality' ratios provided important information, concerning firms' vulnerability. For instance, externalities in the case of Hellenic Halyvourgia were estimated to be up to $10.92 \%$ of EBT, which are significant, considering that the profit margin (i.e. the net income as a percentage of the revenue) of the company in 2004 was $1.3 \%$. Hence, at a hypothetical situation in which a new environmental law, requiring elimination of air emissions, was enforced, the viability of the firm would be probably undermined, although only a time-series analysis could provide a more secure answer.

Concluding, comparing externalities with costs for mitigating environmental impacts may be promising but not sufficiently clear due to the uncertainties involved. Yet, it is evident that there is a growing attempt in EU to more systematically incorporate monetary values in private and public decisionmaking, i.e. in permitting procedures under IPPC jurisdiction, and towards this direction industries must fully understand and implement environmental valuation processes in order to establish a better relationship with the State authorities and the local communities.

\section{Acknowledgements}

This study has been undertaken by the GEVAD Project, which is co-funded by the European Social Fund (75\%) and National Resources (25\%) - Operational 
Programme for Educational and Vocational Training (EPEAEK II) PYTHAGORAS.

\section{References}

[1] International Iron and Steel Institute (IISI), Steel Statistical Yearbook 2007, IISI Committee on Economic Studies: Brussels, pp. 10 - 12, 2007.

[2] European Parliament, Steel Industry, European Parliament Fact Sheets, http://www.europarl.europa.eu/facts/4_7_2_en.htm.

[3] EUROFER, The European Steel Industry and Climate Change, EUROFER: 2000.

[4] Beguin, J-M., Industrial relations in the steel industry, http://www. eurofound.europa.eu/eiro/2004/12/study/tn0412101s.htm.

[5] European Commission, Council Directive 96/61/EC of 24 September 1996 concerning integrated pollution prevention and control, Official Journal L 257, pp. 0026 - 0040, 1996.

[6] European Commission, Integrated Pollution Prevention and Control Reference Document on Economics and Cross-Media Effects, DG JRC, European IPPC Bureau, 2006.

[7] Halyvourgiki S.A., http://www.halyvourgiki.com/english/index.html.

[8] SIDENOR S.A, http://www.sidenor.gr/home.aspx?lang=EN.

[9] Helenic Halyvourgia, http://www.hlv.gr/company-net-1-en.html.

[10] European Commission, Commission Decision of 17 July 2000 on the implementation of a European pollutant emission register (EPER) according to Article 15 of Council Directive 96/61/EC concerning integrated pollution prevention and control (IPPC), Official Journal of the European Communities, L192, pp. 36 - 43, 2000.

[11] AEA Technology Environment, Damages per tonne emission of $P M_{2.5}$, $\mathrm{NH}_{3}, \mathrm{SO}_{2}, \mathrm{NOx}$ and VOCs from each EU25 Member State (excluding Cyprus) and surrounding seas, Service Contract for carrying out costbenefit analysis of air quality related issues, in particular in the CAFE programme, 2005. 